\title{
EVALUATION OF A QUALITATIVE PRECIPITATION . REACTION FOR THE DETECTION OF THE RHEUMATOID FACTOR* $\dagger$
}

\author{
BY \\ WALLACE V. EPSTEIN, $\ddagger$ EPHRAIM P. ENGLEMAN, AND MARGARET ROSS \\ From the Rheumatic Disease Group of the Department of Medicine, and the Metabolic Unit for Research in \\ Arthritis and Allied Diseases, University of California School of Medicine, San Francisco, California
}

The term "rheumatoid factor" (R.F.) has been applied to the substance or substances in the serum of most individuals having rheumatoid arthritis which combines with immune globulins or substances closely associated with immune globulins. The term "rheumatoid" refers to the fact that it is most frequently detected in the serum of individuals having rheumatoid arthritis; it is also found in about one third to one half of patients with disseminated lupus erythematosus and in some sera from patients with other connective tissue diseases (Jacobson, Kammerer, Wolf, Epstein, and Heller, 1956; Ziff, Fallet, Esserman, Lospalluto, and McEwen, 1956). In the Fraction II agglutination test (Heller, Jacobson, Kolodny, and Kammerer, 1954), the R.F. is measured with washed sheep cells coated with Fraction II (F. II) as obtained by the Cohn cold ethanol fractionation technique. The concentration of a substance or substances in the serum which causes the agglutination of such coated cells is taken as a measure of the R.F. content of the serum (F.II Agglutination Titre-Fig. 1, opposite).

A precipitation reaction has been demonstrated in the absence of sheep cells. A solution of Fraction II is added to the serum with subsequent precipitate formation (Epstein, Johnson, and Ragan, 1956). This reaction allows for quantitation of the R.F. content of a given serum by the determination of the nitrogen content of a precipitate.

In this paper the R.F. content of a serum, as measured by such a precipitation reaction, is shown to follow the R.F. content as measured by the F. II agglutination titre. A simple qualitative test for R.F. based upon this reaction is presented.

* Supported in part by a research grant from the National Institute of Arthritis and Metabolic Diseases. A-1229.

+ Presented in part at the Ninth International Congress of Rheumatic Diseases, Toronto, Canada, 1957.

$\ddagger$ Research Fellow of the Arthritis and Rheumatism Foundation.

\section{Materials}

One hundred sera submitted for the F. II agglutination test were selected to include specimens over the entire range of agglutination titres from completely negative to strongly positive. The clinical diagnosis was not considered in this selection. Before analysis, the sera were repeatedly centrifuged in a refrigerated centrifuge at $4^{\circ} \mathrm{C}$. until free of sediment. In addition, one hundred sera obtained at random from the hospital serology laboratory were examined in a four-tube qualitatice procedure to represent the findings to be expected in general hospital population.

A special questionnaire, the patient's hospital recorts and in some cases the patient, were examined in order to arrive at a clinical diagnosis after the laboratory studies had been completed. The classification of the American Rheumatism Association (definite, probable, possible: Ropes, Bennett, Cobb, Jacox, and Jessar, 1957) was used $\overrightarrow{\vec{P}}$ for diagnosis. Since only the group "definite rheumatoid arthritis" is analysed in this paper, there was usually no difficulty in establishing this entity from the questionnaires alone.

\section{Methods}

Quantitative Precipitation Procedure (Fig. 1).-This was carried out in duplicate and involved the addition of $2,780 \mu \mathrm{g}$. nitrogen of Fraction $\mathrm{II}^{*}$ in $p \mathrm{H} 8$ phosphate $\dot{\delta}$ buffered saline to $0.5 \mathrm{ml}$. of the centrifuged serum. The tubes were made up to a final volume of $8 \mathrm{ml}$. with $p \mathrm{H} 8$ buffered saline, and the tubes were maintained at $4^{\circ} \mathrm{C}$. $\frac{}{5}$ for 7 days with daily agitation. The nitrogen content $\frac{D}{D}$ of the washed precipitate was measured by the Markham (1942) modification of the micro-Kjeldahl method. The N supernates of the duplicate tubes were pooled, the haemolytic complement inactivated, and the heterophil $N$ absorbed by adding saline washed sheep erythrocytes. N The residual R.F. and gamma globulin activity of the supernates were measured as described previously (Epstein, Engleman, and Ross, 1957). The amount of ${ }_{C}$ gamma globulin used in the quantitative test was selected $\Phi$ as the amount which would yield maximal precipitation $?$

\footnotetext{
* E. R. Squibb Co. Lot 1680 .
} 
FII AGGLUTINATION TITRE

QUANTITATIVE PRECIPITATION REACTION

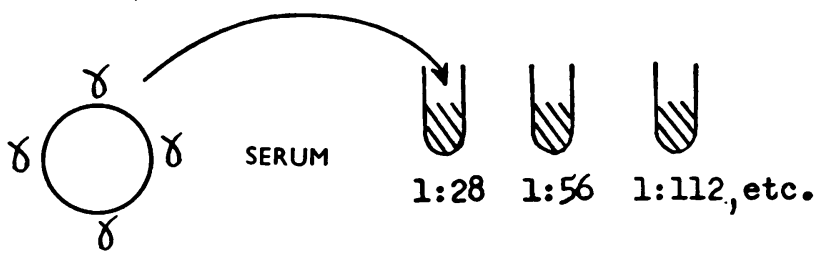

r GLOBULIN + SERUM-PRECIPITATE

READING_NITROGEN DETERMINATION
QUALITATIVE PRECIPITATION REACTION HEATED $~$ GLOBULIN + SERUM

Fig. 1.-Outline of the three methods of measuring rheumatoid factor content of serum by its interaction with human Fraction II (gamma globulin).

and yet avoid the solubilizing effect of an excess of gamma globulin with sera of relatively low F. II agglutination titre.

Qualitative Precipitation Test (Fig. 1).-This involved the addition of Fraction II to four dilutions of serum in $p \mathrm{H} 8$ buffered saline: $1: 20,1: 40,1: 80,1: 160$.

Preparation of Heat-treated Fraction II.-A 5-g. per cent. solution of the same lot of Fraction II as was used for the quantitative study was heated in a water bath to $63^{\circ} \mathrm{C}$. for 10 minutes, as suggested by Franklin, Holman, Müller-Eberhard, and Kunkel (1957). It is uncertain whether the heating causes the formation of non-specific aggregates of partially-denatured protein which are then included into otherwise invisible precipitates, or whether the actual precipitating capacity of the solution of gamma globulin is increased by heat. Gross insoluble matter was removed by centrifugation, the nitrogen content of the slightly opalescent solution was determined, and the solution of heated gamma globulin was diluted to approximately $400 \mu \mathrm{g}$. $\mathrm{N} / \mathrm{ml}$. with $p \mathrm{H} 8$ buffered saline.

Test Procedure.-The heat-treated solution of Fraction II was added in $0.5-\mathrm{ml}$. amounts to each of the four dilutions of serum, and to a $0 \cdot 5-\mathrm{ml}$. buffered saline control. The tubes were mixed and allowed to stand at $4^{\circ}$ C. overnight, then centrifuged at 2,000 r.p.m. for 5 minutes, and read on the basis of the amount of precipitate. This reading was based on a 0 to $4+$ grading of each tube. A $1+$ reaction applied to the presence of shreds of precipitate. A $4+$ reaction appeared as a gelatinous disc which remained intact on mild agitation of the tube. The final reading of this qualitative test was recorded as the summation of points recorded for each of the four tubes. A qualitative score could therefore range from 0 to 16 , the last representing a $4+$ reaction in each of the four dilutions of serum.
The average of the duplicate quantitative determinations was plotted against the F. II agglutination titre. Fig. 2 shows this graph and the line calculated from the regression coefficient. The correlation coefficient ( $r$ ) indicates a significant relationship

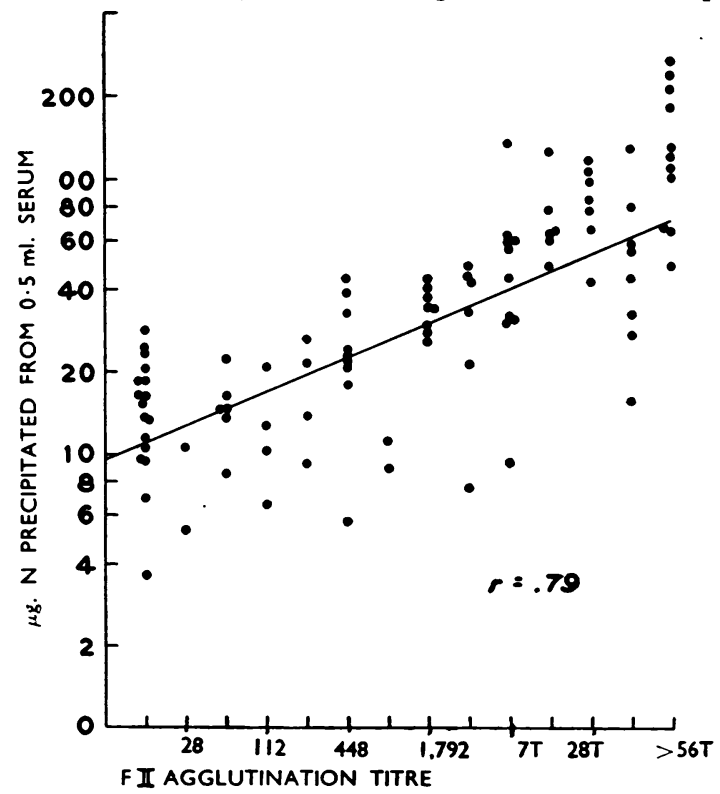

Fig. 2.-Micrograms of nitrogen precipitated from $0.5 \mathrm{ml}$. of sera of different $F$. II agglutination titres by addition of a standard amount of gamma globulin ( $7 T$ in abscissa $=7,000)$. 
between the quantitative precipitation test and the F. II agglutination titre.

Studies of the supernate of the quantitative precipitation tests showed no residual rheumatoid factor except in the sera of agglutination titres in excess of 56,000 , where the highest supernate F. II agglutination titre was $1: 256$. The amount of gamma globulin used in the quantitative test had been chosen as the amount which would produce minimal solubility of the precipitates for the whole group of sera. For sera producing precipitates greater than $20 \mu \mathrm{g} . \mathrm{N} / 0.5 \mathrm{ml}$, the amount of gamma globulin in the supernate (inhibition titre $1: 128$ or less) was insufficient to dissolve the precipitate significantly (Epstein, Engleman, and Ross, 1957).

When using most sera of high F. II agglutination titre in the qualitative test, precipitate formed within an hour; however, all tubes were left at $4^{\circ} \mathrm{C}$. overnight. The tenacious nature of the precipitate on agitation and the clarity of the supernate further contributed to the ease of reading the test. Fig. 3 shows the summation of points in the four dilutions of the qualitative test plotted on an arithmetic scale against the F. II agglutination titres plotted on a logarithmic scale. The correlation coefficient again indicates a significant relationship.

The relationship of the quantitative values (solid dots in clear areas) and the qualitative readings (open dots in shaded areas) for the sera grouped according to F. II agglutination titre is shown in Fig. 4. The general correlation of these readings with each other and with the F. II agglutination titre is obvious.

Two individual exceptions among the sera must be noted:

(i) The serum in the range of F. II agglutination titre 1,792-7,000, showing $135 \mu \mathrm{g}$. $\mathrm{N}$ precipitated from $0.5 \mathrm{ml}$. serum, was obtained from a patient thought to have trichiniasis but who presented many features of periarteritis nodosa.

(ii) The serum of $1: 56,000$ titre showing little precipitate formation quantitatively and none qualitatively was from a case of probable rheumatic fever. The agglutination titre of this patient's serum dropped to zero within 30 days during treatment consisting of rest in bed and salicylate therapy.

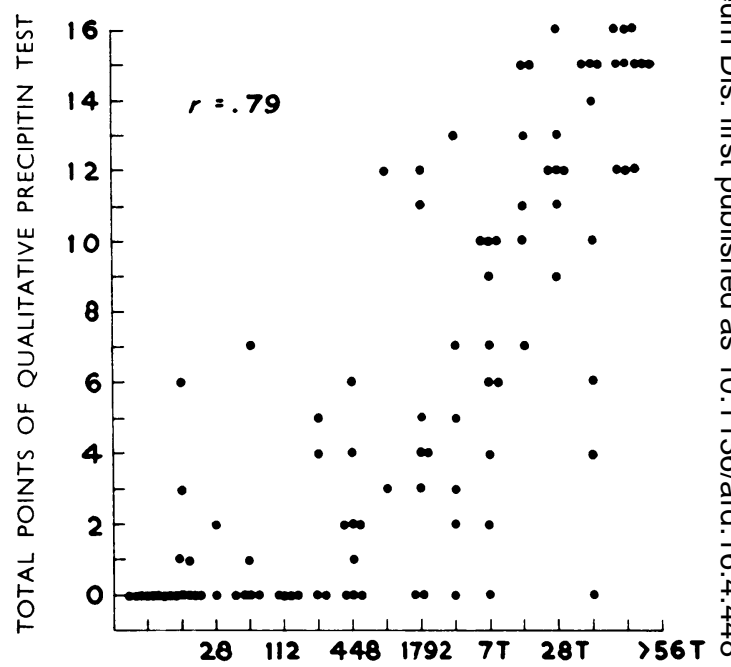

FII AGGLUTINATION TITRE

Fig. 3.-Summation of qualitative precipitation points in sera of different $F$. II agglutination titres.

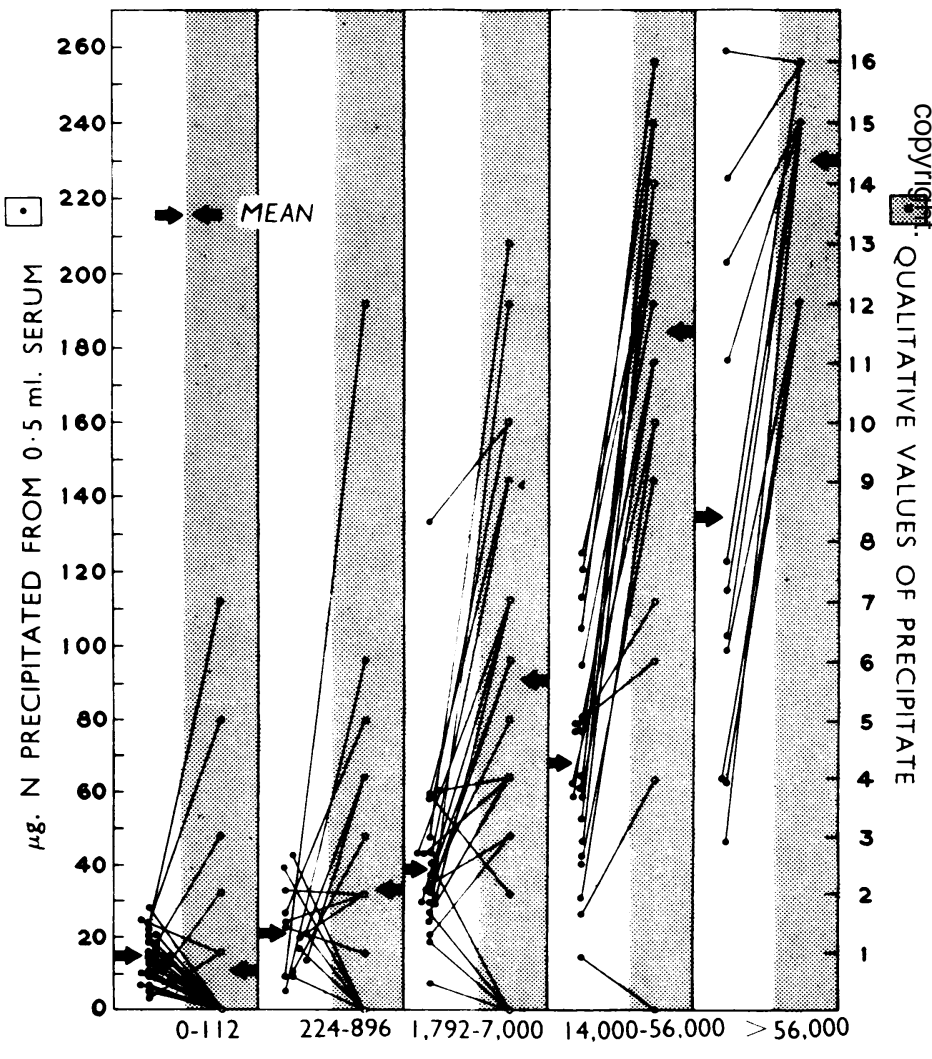

FII AGGLUTINATION TITRE

Fig. 4.-Correlation of individual quantitative and qualitative results relative to the $F$. II agglutination titres of the sera. 
In patients diagnosed as having rheumatoid arthritis, significant change in the F. II agglutination titre has been found to be uncommon despite all modes of therapy (Jacobson and others, 1956). Other sera showing significant disparity between the agglutination titre and precipitation results are being sought.

In our experience, sera with $1: 112$ agglutination titre or higher were almost always associated with patients having some type of connective tissue disease. Table I (A and B) shows an analysis of the qualitative and quantitative determinations, using an F. II agglutination titre of $1: 112$ as the dividing line. The precipitation of 20 or more $\mu \mathrm{g}$. nitrogen or the presence of two or more precipitation points in the four-tube qualitative test were most frequently found in sera with an agglutination titre higher than $1: 112$. The 3 per cent. incidence of false positive control sera in the qualitative precipitation test is similar to that found in a larger survey studied by the F. II agglutination method (Jacobson and others, 1956). As established by $\chi^{2}$ analysis, there is less than one chance in 100 of these relationships occurring by chance.

TABLE IA

ANALYSIS OF QUANTITATIVE RESULTS PER $0.5 \mathrm{ml}$. SERUM

\begin{tabular}{|c|c|c|c|}
\hline \multirow{2}{*}{ F. II } & \multicolumn{3}{|c|}{ Nitrogen Precipitated ( $\mu$ g.) } \\
\hline & 20 or More & Less than 20 & Total \\
\hline $1: 112$ or Less $.112 \ldots$ & $\begin{array}{r}5 \\
63\end{array}$ & $\begin{array}{l}20 \\
12\end{array}$ & $\begin{array}{l}25 \\
75\end{array}$ \\
\hline
\end{tabular}

$P=<0.01$

TABLE IB

ANALYSIS OF QUALITATIVE RESULTS

\begin{tabular}{|c|c|c|c|}
\hline \multirow{2}{*}{ F. II } & \multicolumn{2}{|c|}{ Precipitation Points } & \multirow{2}{*}{ Tota } \\
\hline & 2 or More & Less than 2 & \\
\hline $\begin{array}{l}1: 112 \text { or Less } . \\
\text { Greater than } 1: 112\end{array}$ & $\begin{array}{r}4 \\
60\end{array}$ & $\begin{array}{l}21 \\
15\end{array}$ & $\begin{array}{l}25 \\
75\end{array}$ \\
\hline Control Sera $\ldots$ & 3 & 97 & 100 \\
\hline
\end{tabular}

Of the hundred diagnostic sera analysed in this paper, 38 were found to be from individuals fulfilling the criteria for the diagnosis of definite rheumatoid arthritis. The remaining 62 were mostly from individuals diagnosed as possibly or probably suffering from rheumatoid arthritis. Table II shows the distribution of the sera from the patients having definite rheumatoid arthritis according to the F. II agglutination titre.

TABLE II

CLINICAL DIAGNOSIS

\begin{tabular}{|c|c|c|c|}
\hline \multirow[t]{2}{*}{ F. II Ranges } & \multirow{2}{*}{$\begin{array}{l}\text { Total } \\
\text { Number } \\
\text { of Sera }\end{array}$} & \multicolumn{2}{|c|}{$\begin{array}{c}\text { Cases of } \\
\text { Definite Peripheral } \\
\text { Rheumatoid Arthritis }\end{array}$} \\
\hline & & Number & Per cent. \\
\hline $\begin{array}{c}0-112 \\
224-896 \\
1,792-7,000 \\
14,000-56,000 \\
>56,000\end{array}$ & $\begin{array}{l}29 \\
15 \\
24 \\
21 \\
11\end{array}$ & $\begin{array}{r}5^{*} \\
3 \\
7 \\
14 \\
9\end{array}$ & $\begin{array}{l}17 \\
20 \\
29 \\
67 \\
82\end{array}$ \\
\hline Totals & 100 & 38 & \\
\hline
\end{tabular}

* Three patients also had psoriasis and one patient had juvenile rheumatoid arthritis.

As noted, four of the five sera of $0-1: 112$ titre were from patients with clinical histories frequently associated with a negative agglutination test (Ziff, 1957).

\section{Discussion}

Evaluation of the rheumatoid factor content of serum by any of the methods used in this paper, as it relates to the independent clinical diagnosis, has been simplified by using the small group fulfilling the criteria for definite rheumatoid arthritis and therefore allowing a relative certainty of diagnosis. The R.F. content of serum does not clearly correlate with clinical parameters of inflammation, and is therefore probably not a measure of inflammation per se (Jacobson, and others, 1956). It has been suggested that the presence of the rheumatoid factor can be used as a prognostic guide (Duthie, Brown, Knox, and Thompson, 1957).

Available evidence indicates that the various sheep cell agglutination systems have in common the presence of an immune globulin or some substance associated with immune globulins firmly attached to a particulate object. The attachment occurs because of the antigenic nature of that particle relative to the immune globulin (sheep cells and amboceptor) or represents a physical-chemical union (gamma globulin attached to a red cell via a tannic acid bridge).

It would seem altogether probable that the direct interaction of the gamma globulin and the rheumatoid factor to produce a precipitate would depend upon an identical mechanism as exists in the agglutination systems; however, several differences need be considered:

(1) The sheep cell exposed to its homologous rabbit antiserum may bind components of the antiserum selectively, and the same selective aspect could be true 
for the tannic acid-treated red cell when exposed to a solution of human gamma globulin (Fraction II). In contrast, the precipitation procedure goes on in the presence of all the components of Fraction II.

(2) Serum factors other than those we think of as the rheumatoid factor may be able to exhibit an effect upon the agglutination and not upon the precipitation system or vice versa. This may explain the situation found in the serum of the patient having rheumatic fever.

The spontaneous precipitation of proteins from sera of a high F. II agglutination titre (Epstein, Engleman, and Ross, 1957) is probably a reflection of the presence of large quantities of rheumatoid factor and of a substance similar in action to the commercial Cohn Fraction II added in the direct F. II precipitation procedure. It is in the group of sera of high rheumatoid factor content that proteins or protein complexes of unusually large size have been found (Franklin, and others, 1957).

The question whether the components involved in any of these systems are "natural" or unnatural (denatured) is certainly pertinent. One has no assurance that the constituents of serum reactive in these tests are unaltered in the process of separation from clot. This same question exists for the commercial Fraction II used in the direct precipitation procedure. All sources of Cohn Fraction II studied to date exhibit the capacity of uniting with rheumatoid factor as measured by their ability to inhibit a positive F. II agglutination procedure. Different lots of Cohn Fraction II differ in the degree of this ability to inhibit as well as in the ability to result in a union with rheumatoid factor which leaves solution, i.e. direct precipitation. It seems likely, from the spontaneous precipitation phenomenon in sera of high F. II agglutination titre, that precipitation is not wholly dependent upon denaturation of the gamma globulin during its preparation. In addition, it has been reported that sera from healthy persons differ in their capacity to bind with R.F. (Grubb and Laurell, 1956), or in the case of anti-Rh sera to sensitize cells to the rheumatoid factor (Waller and Vaughan, 1956). The activity of different lots of gamma globulin, representing as they do the pooling of the plasma of many individuals, may show different activities based on the nature of the population pool.

The addition of inorganic particles to serum during spontaneous or F. II induced precipitate formation is of interest, not only because it allows the detection of amounts of precipitate too small to be detected in the absence of such particles, but also because it again suggests the non-specific role of the bacterium or animal red blood cell present in other systems. There is no evidence to date that the addition of latex (Singer and Plotz, 1956), bentonite (Bunim, Bozicevich, and Freund, 1957), or the gamma globulin particles described in this paper convert the reaction from co-precipitation to agglutination. The globulin exposed particles are not washed before being added to the serum in any of these procedures, and therefore there is no evidence that the active globulin component is bound to the particle.

In the qualitative technique described in this paper, molecular aggregates, presumably due to the heating of protein, allow the precipitation reaction to be easily visualized. Whether the heating procedure changes the extent of the underlying gamma globulin factor-rheumatoid factor combination is under study. A similar effect of heat has been reported for the anti-complementary activity of serum (Norgaard, 1955).

Despite lessened sensitivity, the detection of the rheumatoid factor by precipitation techniques offers a real advantage in the study of the kinetics of the reaction. Although the qualitative precipitation procedure is rapid and simple, it should probably be used with and not in place of the agglutination technique, because of the high incidence of negative precipitation results in sera with significant agglutination titres.

\section{Summary}

The rheumatoid factor content of a serum as reflected in the Fraction II (F. II) quantitative precipitation test significantly parallels the rheumatoid factor (R.F.) content measured by the F. II agglutination test. A simple qualitative precipitation test for the R.F. content of serum, requiring only a solution of heated gamma globulin, is described. The results of this simple qualitative test show good correlation with the results of both the quantitative precipitation test and the F. II agglutination test. Evidence is presented for the diagnostic value of carrying out both agglutination and precipitation tests.

We are grateful to Dr. Calvin Zippin of the Cancer Research Institute, University of California Medical Centre, for the statistical analysis. The gamma globulin was obtained through the courtesy of the American National Red Cross, Washington, D.C.

\section{REFERENCES}

Bunim, J. J., Bozicevich, J. and Freund J. (1957). IX International Congress of Rheumatic Diseases, June, 1957. Toronto, Congress of Rheumatic Diseases, June, 1957. Toronto,
Canada.

Duthie, J. J. R., Brown, P. E., Knox, J. D. E., and Thompson, M. (1957). Ibid.

Epstein, W. V., Engleman, E. P., and Ross, M. (1957). J. Immunol. (In press.)

Johnson, A., and Ragan, C. (1956). Proc. Soc. exp. Biol. (N.Y.), 91, 235

Franklin, E. C. Holman, H. R., Müller-Eberhard, H. J., and Kunkel. H. G. (1957). J. exp. Med., 105, 425.

Grubb, R., and Laurell, A.-B. (1956). Acta path. microbiol, scand. 39, 390. 
Heller, G., Jacobson, A. S., Kolodny, M. H., and Kammerer, W. H. (1954). J. Immunol., 72, 66

Jacobson, A. S., Kammerer, W. H., Wolf, J., Epstein, W., and Heller, G. (1956). Amer. J Med., 20, 490

Markham, R. (1942). Biochem. J., 36, 790.

Nørgaard, G. (1955). Acta path. microbiol. scand., 36, 71.

Ropes, M. W., Bennett, G. A., Cobb, S., Jacox, R., and Jessar, R. A. (1957). J. chron. Dis., 5, 630.

Singer, J. M., and Plotz, C. M. (1956). Amer. J. Med., 21, 888.

Waller, M. V., and Vaughan, J. H. (1956). Proc. Soc. exp. Biol. $(N . Y), 92,198$.

Ziff, M., Fallet, G., Esserman, P., and McEwen, C. (1956). of the Rheumatic Diseases, 15, 400.

(1957). J. chron. Dis., 5, 644.

Evaluation de la réaction de précipitation qualitative pour la détection du facteur rhumatismal

RÉSUMÉ

La teneur en facteur rhumatismal d'un sérum, représentée par la fraction II (FII) de la réaction de précipitation quantitative est significativement parallèle à la teneur en facteur rhumatismal (F.R.) mesurée par la réaction d'agglutination pour FII. On décrit ici une simple réaction de précipitation qualitative pour le F.R. dans le sérum, nécessitant seulement une solution de globuline gamma chauffée. Les résultats de cette simple réaction qualitative montrent une bonne corrélation avec les résultats à la fois de la réaction de précipitation quantitative et de celle d'agglutination pour FII. On présente des données concernant la valeur diagnostique autant de la réaction d'agglutination que celle de précipitation.

Valoración de la reacción de precipitación cualitativa para la determinación del factor reumático

\section{Sumario}

En el suero, el factor reumático representado por la fracción II (FII) de la reacción de precipitación cuantitativa es significativamente paralelo al factor reumático (F.R.) medido por la reacción de aglutinación para FII. Se describe aquí una simple reacción de precipitación cualitativa para el F.R. sérico, necesitando solamente una solución de globulina gama calentada. Los resultados de esta simple reacción cualitativa revelan una buena correlación con los resultados a la vez de la reacción de precipitación cuantitativa y de la reacción de aglutinación para la FII. Se presentan los datos respecto al valor diagnóstico tanto de la reacción de aglutinación como de la reacción de precipitación. 